\title{
Penegakan Hukum Lingkungan Menurut UUPLH
}

\section{Zairin Harahap}

\begin{abstract}
The enforcement of enviroment law according to the Enviromental Management Law can be implemented both in a preventive and repressive manner. The enforcement of enviromental law in a preventive manner aims to directly prevent the occurrence of enviromental damage or pollution. The legal instrument used is administrative law, in the format an obligation imposed upon each person who intends to run a business, to first obtain an environmental impact assessment of the proposed business. The represive enforcement of law aims to reduce and abate existing environmental damage of pollution by using administrative law civil law and criminal law.
\end{abstract}

\section{Pendahuluan}

Pembangunan tidak hanya mendatangkan sejumlah dampak positif (manfaat) bagi kelangsungan kehidupan manusia dan lingkungan hidup. Tetapi, dalam waktu yang bersamaan juga sekaligus dapat mendatangkan sejumlah ancaman (dampak negatif yang berupa risiko) bagi kelangsungan kehidupan umat manusia dan lingkungan hidup an-sich. ${ }^{1}$ Pembangunan di bidang transportasi dan industri telah memberikan manfaat yang sangat besar bagi umat manusia dalam memenuhi kebutuhan hidupnya. Ini adalah sekedar contoh kecil dari manfaat pembangunan.
Namun, dalam waktu yang bersamaan pembangunan di bidang transportasi dan industri telah menimbulkan berbagai perusakan (damage) dan pencemaran lingkungan hidup (pollution). Pencemaran udara akibat asap kendaraan bermotor dan industri serta munculnya gejala krisis air bersih akibat pembuangan limbah oleh industri yang tak terkendali merupakan contoh kecil dari dampak negatif yang ditimbulkan oleh pembangunan. ${ }^{2}$

Sejalan dengan pertambahan jumlah penduduk, kebutuhan manusia terhadap sumber daya alam secara otomatis juga

'Baca antara lain Otto Soemarwoto, Ekologi, Lingkungan Hidup dan Pembangunan, Cetakan Keenam (Jakarta: Penerbit Djambatan, 1994), hlm. 150-152.

${ }^{2}$ Antara lain dapat dibaca Bernadette West, Peter M. Sandman, dan Michael R. Greenberg, Panduan Pemberitaan Lingkungan Hidup (Jakarta: Yayasan Obor Indonesia, 1998), hlm. 66-73; Sri Widiati (Penterjemah), Planet Kita Kesehatan Kita: Laporan Komisi WHOMengenaiKesehatan dan Lingkungan (Yogyakarta: Gadjah Mada University Press, 2001), hlm. 205-219. 
bertambah yang dapat menyebabkan terjadinya penurunan atau kelangkaan sumberdaya disebabkan oleh pertumbuhan penduduk. ${ }^{3}$ Sementara dalam waktu yang bersamaan lahan sumber daya alam akan semakin berkurang sebagai konsekuensi logis pemenuhan kebutuhan manusia seperti untuk pemukiman, transportasi, perkantoran, pendidikan, dan sektor-sektor perekonomian. Agar seluruh kebutuhan manusia tersebut dapat terpenuhi, maka mau tidak mau manusia harus melakukan aktivitas pembangunan.

Pembangunan tidak bisa dilepaskan dengan ketergantungannya terhadap pemanfaatan sumber daya alam (natural resources). Di dalam pemanfaatan sumber daya alam tersebut sangat potensial mendatangkan sejumlah konflik kepentingan antara satu warga masyarakat dengan warga masyarakat lainnya, antara pengusaha dan warga masyarakat, antara pengusaha dan pemerintah, dan antara warga masyarakat dengan pemerintah. Karena, dalam konteks yang demikian siapapun menjadi sangat potensial melakukan perusakan dan atau pencemaran lingkungan yang menimbulkan kerugian bagi pihak lain.

Untuk mengantisipasi munculnya konflik tersebut sekaligus untuk menyelesaikan konflik yang muncul diperlukan adanya suatu aturan hukum. Dewasa ini, aturan hukum yang dimaksud adalah Undang-undang Nomor 23 Tahun 1997 tentang Pengelolaan Lingkungan Hidup (UUPLH).

\section{Sistem Penegakan Hukum Lingkungan}

Penegakan hukum lingkungan tidak hanya ditujukan untuk memberikan hukuman kepada perusak atau pencemar lingkungan hidup. Tetapi, juga ditujukan untuk mencegah terjadinya perbuatan atau tindakan yang dapat menimbulkan perusakan dan atau pencemaran lingkungan hidup. Oleh karena itu, penegakan hukum lingkungan tidak hanya bersifat represif, tetapi juga bersifat preventii. ${ }^{4}$

Penegakan hukum lingkungan yang bersifat represif ditujukan untuk menanggulangi perusakan dan atau pencemaran lingkungan dengan menjatuhkan atau memberikan sanksi (hukuman) kepada perusak atau pencemar lingkungan yang dapat berupa sanksi pidana (penjara dan denda), sanksi perdata (ganti kerugian dan atau tindakan tertentu), dan atau sanksi administrasi (paksaan pemerintahan, uang paksa, dan pencabutan izin).

Sedangkan penegakan hukum lingkungan yang bersifat preventif ditujukan untuk mencegah terjadinya perbuatan atau tindakan yang dapat menimbulkan perusakan atau pencemaran lingkungan. Dewasa ini, instrumen hukum yang ditujukan untuk penegakan hukum lingkungan yang bersifat preventif ini adalah AMDAL (Analisis Mengenai Dampak Lingkungan) dan Perizinan.

Dengan demikian, penegakan hukum lingkungan yang bersifat represif dilakukan setelah adanya perbuatan atau tindakan yang mengakibatkan terjadinya perusakan atau

${ }^{3}$ Bruce Mitchell, B. Setiawan, dan Dwita Hadi Rahmi, Pengelolaan Sumberdaya dan Lingkungan (Yogyakarta: Gadjah Mada University Press, 2000), hlm. 10.

${ }^{4}$ Siti Sundari Rangkuti, Hukum Lingkungan dan Kebijaksanaan Lingkungan Nasional, Edisi Kedua (Surabaya: Airlangga University Press, 2000), hlm. 209-210. 
pencemaran lingkungan. Sedangkan penegakan hukum preventif lebih bersifat mencegah agar perbuatan atau tindakan itu tidak menimbulkan perusakan atau pencemaran lingkungan. Jadi, dilakukan sebelum terjadinya perusakan atau pencemaran lingkungan.

UUPLH mengenal ketiga jenis sanksi tersebut di atas yang dapat dikenakan kepada pelaku perusakan atau pencemaran lingkungan. Tidak ada larangan ketiga jenis sanksi tersebut dikenakan kepada peläku secara sekaligus meskipun untuk kasus yang sama. Pengenaan ketiga jenis sanksi tersebut secara sekaligus kepada pelaku perusakan atau pencemaran lingkungan bukanlah merupakan ne bis in idem..$^{5}$ Sanksi Administrasi diatur dalam Pasal 25, 26, dan Pasal 27 UUPLH, Sanksi Perdata diatur dalam Pasal 34 dan Pasal 35, sedangkan Sanksi Pidana diatur dalam Pasal 41, 42, 43, 44, 45, 46 dan Pasal 47 UUPLH.

Meskipun demikian, pengenaan atau penjatuhan sanksi administrasi terhadap setiap kasus perusakan atau pencemaran lingkungan haruslah terlebih dahulu mendapatkan prioritas utama. Dengan kata lain, penjatuhan sanksi administrasi haruslah mendahului sanksi-sanksi lainnya. Hal ini didasarkan kepada bahwa sifat dari sanksi administratif itu adalah langsung ditujukan untuk menyelesaikan sumber masalahnya.
Tidak demikian halnya dengan sanksi pidana yang bertujuan memenjarakan pelaku atau penjatuhan sanksi perdata yang bertujuan. penuntutan ganti kerugian. Kedua jenis sanksi tersebut sangat jelas tidak ditujukan langsung untuk menyelesaikan sumber masalahnya. Berapapun beratnya sanksi pidana yang dijatuhkan dan berapapun besarnya ganti kerugian yang dibayarkan tidaklah ada kaitannya dengan penyelesaian sumber masalahnya. Perusakan dan atau pencemaran lingkungan tetap saja berlangsung, bahkan mungkin dampaknya sangat potensial semakin meluas.

\section{Penyelesaian Sengketa Lingkungan Hidup}

Dalam Pasal 30 Undang-undang Nomor 23 Tahun 1997 tentang Pengelolaan Lingkungan Hidup (UUPLH) disebutkan:

(1) Penyelesaian sengketa lingkungan hidup dapat ditempuh melalui pengadilan atau di luar pengadilan berdasarkan pilihan sukarela para pihak yang bersengketa;

(2) Penyelesaian sengketa di luar pengadilan sebagaimana dimaksud pada ayat (1) tidak berlaku terhadap tindak pidana lingkungan hidup sebagaimana diatur dalam undang-undang ini;

(3) Apabila telah dipith upaya penyelesaian sengketa lingkungan hidup di luar

${ }^{5}$ Muladi, "Prinsip-prinsip Dasar. Hukum Pidana Lingkungan dalam Kaitannya dengan UU Nomor 23 Tahun 1997," Makalah Disampaikan pada Seminar Nasional yang Diselenggrakan oleh Fakultas Hukum Universitas Dipanegoro, Semarang, 21 Februari 1998, hlm. 10. Bandingkan dengan Philipus M. Hadjon, "Penegakan Hukum Administrasi dalam Pengelolaan Lingkungan Hidup," dalam. B. Arief Sidharta, dkk (Editor), Butir-butir Gagasan tentang Penyelenggaraan Hukum dan Pemerintahan yang Layak (Bandung: Penerbit PT. Citra Aditya Bakti, 1996), hlm. 343. 
pengadilan; gugatan melalui pengadilan hanya dapat ditempuh apabila upaya tersebut dinyatakan tidak berhasil oleh salah satu atau para pihak yang bersengketa.

Dari ketentuan Pasal 30 UUPLH tersebut dapat diketahui bahwa penyelesaian sengketa lingkungan tidak harus diselesaikan melalui pengadilan. Tetapi, juga dapat diselesaikan di luar pengadilan dengan catatan-catatan sebagai berikut:

1. penyelesaian sengketa di luar pengadilan tersebut merupakan kehendak dari para pihak yang berselisih atau bersengketa, bukan hanya kehendak salah satu pihak saja;

2. apabila kedua belah pihak telah bersepakat untuk menyelesaikan sengketanya di luar pengadilan, maka salah satu pihak dalam waktu yang bersamaan tidak boleh mengajukan gugatan ke pengadilan;

3. penyelesaian sengketa melalui pengadilan atau gugatan melalui pengadilan hanya dapat dilakukan setelah penyelesaian secara di luar pengadilan itu menemui jalan buntu atau salah satu pihak menarik diri;

4. penyelesaian sengketa di luar pengadilan hanya terbatas pada masalah keperdataan. Oleh karena itu, yang menyangkut masalah pidana lingkungan tidak dapat diselesaikan di luar pengadilan (musyawarah).

Namun, perlu dipahami bahwa apabila salah satu pihak sejak awal tidak menghendaki penyelesaian sengketa lingkungan tersebut melalui di luar pengadilan. Dengan kata lain langsung memilih untuk menyelesaikan kasus tersebut melalui pengadilan tidaklah menyalahi ketentuan Pasal 30 UUPLH. Penyelesaian sengketa lingkungan melalui di luar pengadilan bukanlah suatu prosedur atau dalam bahasa hukum administrasi yang disebut dengan istilah "upaya administratif" sebagaimana yang diatur dalam Pasal $48 \mathrm{UU}$ 5 Tahun 1986. Penyelesaian sengketa lingkungan melalui di luar pengadilan berdasarkan ketentuan Pasal 30 UUPLH adalah merupakan pilihan sukarela dari para pihak yang bersengketa. Jadi, penyelesaian sengketa melalui di luar pengadilan bukanlah suatu prosedur atau kewajiban yang harus di tempuh terlebih dahulu sebelum mengajukan gugatan ke pengadilan.

\section{Penyelesaian Sengketa Lingkungan Hidup di Luar Pengadilan}

Dalam Pasal 31 UUPLH disebutkan bahwa "Penyelesaian sengketa lingkungan hidup di luar pengadilan diselenggarakan untuk mencapai kesepakatan mengenai bentuk dan besarnya ganti rugi dan atau mengenai tindakan tertentu guna menjamin tidak akan terjadinya atau terulangnya dampak negatif terhadap lingkungan hidup." Dari ketentuan pasal tersebut dapat disimpulkan hal-hal sebagai berikut:

- penyelesaian sengketa di luar pengadilan dilakukan untuk mencapai kesepakatan;

- kesepakatan sebagaimana dimaksud berkaitan dengan bentuk penyelesaian dan besarnya ganti rugi yang akan diterima oleh korban;

- di samping itu, pencemar harus melakukan tindakan-tindakan tertentu guna menjamin tidak terjadinya atau terulangnya dampak negatif lagi. 


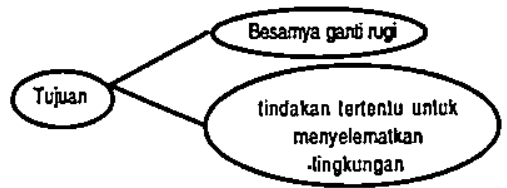

\subsection{Penggunaan Jasa Pihak Ketiga}

Dalam Pasal 32 UUPLH disebutkan bahwa "Penyelesaian sengketa lingkungan hidup di luar pengadilan sebagaimana dimaksud dalam Pasal 31 dapat digunakan jasa pihak ketiga, baik yang tidak memiliki kewenangan mengambil keputusan maupun yang memiliki kewenangan mengambil keputusan, untuk membantu menyelesaikan sengketa lingkungan hidup."

Kata dapat pada ketentuan pasal tersebut mengandung makna:

- penyelesaian sengketa lingkungan di luar pengadilan dapat dilakukan sendiri oleh pihak-pihak yang bersengketa tanpa bantuan pihak ketiga. Penyelesaian dalam bentuk ini disebut dengan negosiasi, ${ }^{6}$

- namun, pihak-pihak yang bersengketa juga dapat meminta bantuan jasa pihak ketiga untuk menyelesaikan sengketa mereka. Jika menggunakan jasa pihak ketiga yang tidak memiliki kewenangan untuk mengambil keputusan disebut dengan penyelesaian sengketa melalui mediasi. ' Jika mènggunakan jasa pihak ketiga yang memiliki kewenangan untuk mengambil keputusan disebut dengan penyelesaian sengketa melalui arbitrase. ${ }^{8}$

\subsection{Pembentukan Lembaga Penyedia Jasa}

Dalam Pasal 33 UUPLH disebutkan:

(1) Pemerintah dan atau masyarakat dapat membentuk lembaga penyedia jasa pelayanan penyelesaian sengketa lingkungan hidup yang bersifat bebas dan tidak berpihak;

(2) Ketentuan mengenai penyedia jasa pelayanan penyelesaian sengkèta lingkungan hidup diatur lebih lanjut dengan Peraturan Pemerintah.

Dari ketentuan pasal tersebut dapat diketahui bahwa lembaga penyedia jasa pelayanan penyelesaian sengketa lingkungan baik melalui mediasi maupun arbitrase dapat dibentuk oleh pemerintah maupun swasta. Sedangkan Peraturan Pemerintah sebagaimana dimaksud ayat (2) tersebut adalah Peraturan Pemerintah Nomor 54 Tahun 2000 tentang Lembaga Penyedia Jasa Pelayanan Penyelesaian Sengketa Lingkungan Hidup di Luar Pengadilan.

\section{Penyelesaian Sengketa Lingkungan Melalui Pengadilan:}

\subsection{Gugatan Ganti Kerugian}

Penyelesaian sengketa lingkungan melalui pengadilan dapat dilakukan dengan melakukan gugatan ke Pengadilan Umum untuk kasus perdata lingkungan dengan gugatan ganti kerugian dan gugatan ke

${ }^{6}$ Sebagai perbandingan dapat dibaca antara lain buku yang ditulis oleh Gunawan Widjaja, Alternatif Penyelesaian Sengketa (Jakarta: Rajawali Pers, 2001), hlm. 87; dan Joni Emirzon, Alternatif Penyelesaian Sengketa di Luar Pengadilan (Negosiasi, Mediasi, Konsiliasi \& Arbitrase) (Jakarta: PT Gramedia Pustaka Utama, 2000), hlm. 44.

${ }^{7}$ Gunawan Widjaja, ibid, hlm. 90-93.

${ }^{8} \mathrm{lbid}$, hlm. 94 - 97. 
Pengadilan Tata Usaha Negara untuk kasus administrasi lingkungan dengan obyek sengketanya KTUN (Keputusan Tata Usaha Negara) sebagaimana yang diatur dalam Undang-undang Nomor 5 Tahun 1986 tentang Peradilan Tata Usaha Negara jo Undang-undang Nomor 9 Tahun 2004 tentang Perubahan atas Undang-undang Nomor 5 Tahun 1986 tentang Peradilan Tata Usaha Negara.

Gugatan ke Pengadilan Umum dapat dilakukan dengan $3^{\prime}$ (tiga) cara, yaitu; gugatan ganti kerugian (Pasal 34 dan Pasal 35 UUPLH), gugatan perwakilan atau class action (Pasal 37 UUPLH), dan gugatan legal standing (Pasal 38 UUPLH).

Tuntutan ganti kerugian menurut UUPLH hanyalah dapat dilakukan oleh korban perusakan dan atau pencemaran lingkungan. Pasal 34 menganut asas.liability based on fault dan oleh karená itu menjadi tanggung jawab korban (penggugat) untuk membuktikan adanya hubungan kausalitas antara kerugian yang mereka derita dengan perbuatan yang dilakukan oleh pihak perusak atau pencemar lingkungan.

Selanjutnya dalam Pasal 34 itu juga disebutkan bahwa selain tuntutan ganti kerugian, penggugat juga dapat mengajukan tuntutan untuk melakukan tindakan tertentu terhadap tergugat, misalnya; dalam kasus pencemaran air, maka dapat menuntut agar tergugat memasang air bersih ke rumahrumah warga yang sumurnya tercemar berikut menanggung biayanya selama sumurnya belum dapat dipergunakan sebagaimana mestinya dan memulihkan fungsi lingkungan. Di samping itu, hakim juga dapat menetapkan uang paksa atas setiap hari keterlambatan penyelesaian tindakan tertentu tersebut.
Dengan demikian, tergugat akan termotivasi untuk segera melaksanakan kewajibannya. Karena, jika tidak, pencemar akan terus terbebani oleh uang paksa atas ketidakpatuhannya itu.

Gugatan atau tuntutan ganti kerugian dapat juga didasarkan kepada Pasal 35 UUPLH yang menganut asas strict liability (asas tangung jawab mutlak atau asas tanggung jawab langsung dan seketika) yang dilkuti dengan prinsip shitting of burden of proof atau omkering van bewijlast (pembuktian terbalik; artinya yang dibebani untuk pembuktian adalah tergugat dalam hal ini pencemar bukan penggugat atau korban).

Gugatan atau tuntutan yang didasarkan kepada Pasal 35 UUPLH mempunyai persamaan dan perbedaan dengan gugatan atau tuntutan yang didasarkan kepada pasal 34 UUPLH. Pasal 34 UUPLH lebih bersifat lex generalis, sedangkan ketentuan Pasal 35 bersifat lex specialis. Artinya, dasar hukum untuk menuntut ganti kerugian dalam kasus perusakan dan atau pencemaran lingkungan pada dasarnya menggunakan ketentuan Pasal 34 UUPLH, kecuali kasus-kasus yang terkait sebagaimana yang disebutkan dalam. ketentuan Pasal 35 UUPLH.

Asas liability based on fault adalah suatu sistem tanggung jawab atas dasar kesalahan. Oleh karena itu, berdasarkan ketentuan Pasal 1365 KUHPerdata tentang perbuatan melawan hukum (onrechtmatige daad) yang dikaitkan dengan ketentuan Pasal 1865 KUHPerdata tentang beban pembuktian (bewijslast). Maka, menjadi kewajiban penggugat (korban pencemaran) untuk membuktikan adanya hubungan kausal antara kerugian yang dideritanya dengan perbuatan pencemaran yang dilakukan oleh tergugat 
(pencemar). Sistem pembuktian iłu disebut juga dengan sistem pembuktian ilmiah (scientific proof system). Dalam sistem pembuktian itu tidak cukup hanya membuktikan adanya suatu atau beberapa fakta. Karena, bisa jadi fakta-fakta itu tidak memiliki kausalitas antara satu dengan lainnya. Dalam suatu kasus, bisa saja telah terbukti terjadinya perusakan atau pencemaran lingkungan dan juga terbukti bahwa perusahaan $X$ telah membuang limbah ke lingkungan itu. Namun, adanya kedua fakta itu tidak dapat langsung disimpulkan bahwa penyebab terjadinya perusakan atau pencemaran lingkungan adalah akibat limbah yang dibuang oleh perusahaan $X$. Untuk sampai pada kesimpulan seperti itu harus pula dibuktikan adanya hubungan kausalitas antara keduanya.

Sementara itu, penerapan asas srict liability (asas tanggung jawab mutlak) yang diikuti dengan prinsip shifting of burden of proof (prinsip beban pembuktian terbalik) berdasarkan ketentuan Pasal 35 UUPLH bersifat limitatif. Penerapan asas dan prinsip tersebut hanya terbatas pada kasus-kasus perusakan dan atau pencemaran lingkungan yang terkait dengan; (1) usaha dan atau kegiatan yang menimbulkan dampak beśar dan penting terhadap lingkungan; (2) usaha dan atau kegiatan yang menggunakan bahan berbahaya dan beracun (B3); dan atau (3) usaha atau kegiatan yang menghasilkan limbah bahan berbahaya dan beracun (B3).

Dengan diterapkannya asas dan prinsip ini, maka yang berkewajiban untuk membuktikan adanya perusakan dan atau pencemaran lingkungan adalah pihak tergugat. Dengan kata lain, pihak tergugat harus dapat membuktikan bahwa perusakan dan atau pencemaran lingkungan itu bukan diakibatkan oleh usaha dan atau kegiatannya. Jika tergugat tidak dapat membuktikannya, maka secara otomatis perusakan dan atau pencemaran lingkungan itu telah terbukti disebabkan oleh usaha atau kegiatannya. Oleh karena itu ia wajib membayar ganti kerugian yang dituntut oleh penggugat.

Untuk dapat menerapkan asas strict liability dan prinsip shifting of burden of proof pada suatu kasus perusakan atau pencemaran lingkungan, maka pertama kali yang harus diperhatikan dan sekaligus dipastikan adalah apakah usaha dan atau kegiatan tersebut termasuk salah satu dari usaha dan atau kegiatan yang disebutkan dalam ketentuan Pasal 35 UUPLH tersebut? Jika tidak, maka penyelesaian kasus (sengketa) tersebut tunduk pada ketentuan Pasal 34 UUPLH tidak dapat menerapkan Pasal 35 UUPLH. Jika termasuk, maka hal itu akan sangat membantu warga untuk mendapatkan keadilan. Mengingat, membuktikan adanya hubungan kausalitas itu bukanlah sesuatu yang mudah.

Di samping itu, perlu diketahui bahwa menurut ketentuan Pasal 35 UUPLH tersebut penerapan asas strict liability yang diikuti dengan prinsip shifting of burden of proof tersebut hanyalah menyangkut kasus perdata lingkungan (gugatan ganti kerugian). Sementara yang berkaitan dengan kasus pidana lingkungan tidak dapat diterapkan asas strict liability dan prinsip shifting of burden of proof. Sebagaimana dikemukakan oleh Barda Nawawi Arief, ${ }^{9}$ dengan tercantumnya unsur

${ }^{9}$ Barda Nawawi Arief, Masalah Penegakan Hukum dan Kebijakan Penanggulangan Kejahatan (Bandung: Penerbit PT. Citra Aditya Bakti, 2001), hlm.108. 
sengaja atau kealpaan, maka dapat dikatakan bahwa pertanggungjawaban pidana dalam UUPLH menganut prinsip liability based on fault. Merskipun, secara teoritis dimungkinkan adanya penyimpangan terhadap asas kesalahan dengan menggunakan asas strict liability atau vicarious liability. Oleh karena itu, apa yang dikemukakan oleh Fredrik J. Pinakunary. ${ }^{10}$

Agar hakim berani menerapkan asas strict liability untuk kasus pidana lingkungan di satu sisi akan menyentuh rasa keadilan, namun di-sisi laiñ itu bertentangan dengan asas kepastian hukum.

\subsection{Gugatan Perwakilan (Class Action)}

Korban dari kasus perusakan dan atau pencemaran lingkungan dapat dalam jumlah yang cukup banyak. Oleh karena itu, apabila berniat mengajukan gugatan ke pengadilan adalah lebih tepat dengan mengajukan gugatan-perwakilan atau yang sering disebut sebagai gugatan class action. Unsur-unsur gugatan class action sebagaimana yang disebutkan dalam Pasal 37 adalah; (1) hak sejumlah kecil masyarakat untuk mewakili diri mereka sendiri (class representative) dan orang lain dalam jumlah yang besar (class members); (2) pihak yang diwakili dalam jumlah yang besar (numerousity of class members), dan; (3) kesamaan permasalahan, fakta hukum, dan tuntutan antara yang mewakili dan diwakili (commonality).

Dengan demikian, LSM lingkungan tidak memiliki hak untuk mengajukan gugatan class action, karena mereka bukanlah termasuk korban (pihak yang mengalami kerugian nyata). Sedangkan, Bapedalda Provinsi atau Kantor Pengendalian Dampak Lingkungan Kota/Kabupaten selaku instansi pemerintah yang bertanggung jawab di bidang lingkungan hidup di daerah, berdasarkan ketentuan Pasal 37 ayat (2) dapat mengajukan gugatan class action untuk kepentingan masyarakat, meskipun bukan termasuk korban. Oleh karena itu, ketika masyarakat (korban) dalam keadaan bingung dan semacamnya, mestinya Bappedalda Provinsi dan atau Kantor Pengendalian Dampak Lingkungan Kota/ Kabupaten dapat bertindak cepat mengajukan gugatan class action untuk membela kepentingan para korban itu. Dengan demikian, berdasarkan pasal tersebut, Bappedalda Provinsi atau Kantor Pengendalian Dampak Lingkungan Kota/Kabupaten tidak memiliki hak untuk menuntut ganti kerugian untuk dan atas nama kepentingannya.

Memang UUPLH tidak menyebutkan secara tegas berapa jumlah minimal dari korban yang banyak itu. Tetapi setidaktidaknya, berdasarkan Peraturan Mahkamah Agung Nomor 1 Tahun 2002 tentang Acara Gugatan Perwakilan Kelompok menyebutkan băhwa jumlah yang banyak itu sehingga tidak efektif dan efisien apabila gugatan dilakukan secara sendiri-sendiri atau sécara bersamasama dalam satu gugatan. Dalam Pasal 2 disebutkan secara tegas persyaratan gugatan class action adalah sebagai berikut:

1. Jumlah anggota kelompok sedemikian banyak sehingga tidaklah praktis dan efisien apabila pengajuan gugatan

${ }^{10}$ Fredrik J. Pinakunary, "Penerapan Tanggung Jawab Pidana Mutlak Pada Perkara Pencemaran Lingkungan," http://www. hukumomline. com/detail.asp?id=10837\&cl=Kolom, diakses tanggal 26 November 2004, jam 13.20 WIB. 
dilakukan secara sendiri-sendiri;

2. Terdapat kesamaan fakta atau peristiwa dan kesamaan dasar hukum yang digunakan yang bersifat substansial, serta terdapat kesamaan jenis tuntutan di antara wakil kelompok dengan anggota kelompoknya;

3. Wakil kelompok memiliki kejujuran dan kesungguhan untuk melindungi kepentingan anggota kelompok yang diwakilinya.

Dengan tidak ditentukannya secara tegas jumlah minimal korban untuk dapat mengajukan gugatan class action, maka jumlah minimal tersebut menjadi relatif sifatnya, karena penafsiran terhadap poin1 sepenuhnya menjadi wewenang hakim. Oleh karena itu, kemungkinan terjadinya perbedaan jumlah minimal itu antara penafsiran hakim yang satu dengan yang lain menjadi terbuka lebar. Begitu juga yang berkaitan dengan poin 3 sangat tergantung pada kearifan sang hakim sebelum menerima gugatan class action tersebut. Hal tersebut penting menjadi pertimbangan bijak dari hakim untuk mencegah sang wakil kelompok (class representatives) yang hanya mementingkan keuntungan pribadi dengan mengeksploitasi pihak-pihak yang diwakilinya (class member).

Meskipun demikian, menurut Mas Achmad Santoso," paling tidak ada tiga manfaat yang diperoleh apabila gugatan atas kasus ini dilakukan dengan class action; Pertama, proses berperkara menjadi ekonomis (judicial economy); Kedua, memberikan akses pada keadilan (access to justice); Ketiga, untuk mengubah sikap pelaku pelanggaran (behaviour modification). Hal yang sama juga dikemukan Susanti Adi Nugroho, ${ }^{12}$ bahwa seperti di negara-negara lain tujuan atau manfaat dari gugatan class action adalah; (1) Agar supaya proses berperkara lebih ekonomis dan biaya lebih efisien (judicial economy); (2) Memberikan akses pada keadilan dan mengurangi hambatan-hambatan bagi penggugat individual yang pada umumnya berposisi lemah (the right of groups of people who individually would be without effective strength to bring their opponents into court); (3) Merubah sikap pelaku pelanggaran dan menumbuhkan sikap jera bagi mereka yang berpotensi untuk merugikan kepentingan masyarakat luas (behaviour modification / to punish corporate wrong doing, and to force corporates to pay for any harm they have caused).

\subsection{Gugatan Legal Standing}

Organisasi Lingkungan (LSM lingkungan) tidak berhak mengajukan tuntutan ganti kerugian, kecuali sebatas biaya atau pengeluaran riil. Hak yang utama dari LSM lingkungan adalah mengajukan gugatan untuk kepentingan pelestarian fungsi lingkungan hidup. Hak itu dikenal dengan istilah ius standi yaitu hak atau kualitas untuk tampil dan bertindak sebagai penggugat dalam hukum di pengadilan (persona standi in judicio). ${ }^{13}$ Namun, berdasarkan Pasal 38 ayat (3) tidak

\footnotetext{
"Mas Achmad Santosa, dkk, Gugatan Claas Action (Jakarta: ICEL, 1999).

${ }^{12}$ Susanti Adi Nugroho, Praktek Gugatan Perwakilan Kelompok (Class Action) di Indonesia (Jakarta: Mahkamah Agung Rl, 2002), hlm. 5-6.

${ }^{13}$ Paulus Effendie Lotulung, "Penegakan Hukum Lingkungan dalam UU 23 Tahun 1997 Ditinjau dari Aspek Hukum Perdata," Makalah Disampaikan pada Seminar Nasional yang diselenggarakan oleh Fakultas Hukum Universitas Dipanegoro, Semarang, 21 Februari 1998, hlm. 8.
} 
semua LSM lingkungan dapat mengajukan gugatan ius standi itu. Ada 3 (tiga) syarat yang harus dipenuhi; Pertama, berbentuk badan hukum atau yayasan; Kedua, dalam anggaran dasarnya menyebutkan dengan tegas bahwa tujuan didirikannya organisasi tersebut adalah untuk kepentingan pelestarian fungsi lingkungan hidup; Ketiga; telah melaksanakan kegiatan sesuai dengan anggaran dasarnya. -... Beñỹañ démikian, jika mengacu pada UUPLH, maka sangat jelas bahwa apabila terjadi perusakan dan atau pencemaran lingkungan, maka penyelesaiannya bukanlah semata-mata urusan pihak perusak dan atau pencemar dengan para korban saja. Perusakan dan atau pencemaran lingkungan tidak hanya mendatangkan. kerugian bagi manusia saja, tetapi juga bagi lingkungan. Oleh karena itu, tuntutan atau gugatan terhadap perusak dan atau pencemar lingkungan tidak hanya dapat dilakukan oleh para korban saja, tetapi juga oleh pemerintah (dalam hal ini Gubernur atau pejabat yang mendapat pelimpahan wewenang), dan serta Jaksa apabila menyangkut pidana lingkungan berdasarkan pemeriksaan yang dilakukan oleh Polisi atau PPNS. Tetapi, juga LSM dalam rangka memperjuangkan hak-hak lingkungan yang bertujuan untuk menyelamatkan lingkungan dari berbagai perusakan dan atau pencemaran.

Kecakapan LSM tampil dimuka pengadilan didasarkan pada suatu asumsi LSM sebagai "wali" (guardian) dari lingkungan. Pendapat ini berangkat dari teori yang dikemukakan oleh Cristoper Stone yang memberikan hak hukum (legal right) kepada obyek-obyek alam (natural objects). Menurur Stone, hutan, laut, atau sungai sebagai obyek alam layak memiliki hak hukum dan adalah tidak bijaksana jika dianggap sebaliknya hanya dikarenakan sifatnya yang inanimatif (tidak dapat bicara). ${ }^{14}$ Diterimanya pengambangan teori dan penerapan standing ini menurut Mas Achmad Santoso, setidak-tidaknya didasarkan pada 2 (dua) hal, yaitu; faktor perlindungan kepentingan masyarakat luas, dan faktor penguasaan sumber daya alam atau sektorsektor yang memiliki dimensi publik yang luas oleh negara. ${ }^{15}$

\section{Penjatuhan Sanksi Administratif}

Penjatuhan sanksi administratif kepada pelaku perusakan atau pencemaran lingkungan tidak harus melalui putusan pengadilan. Penjatuhan sanksi administratif dapat langsung dijatuhkan oleh pejabat yang berwenang terhadap pelaku perusakan atau pencemaran lingkungan. Menurut UUPLH ada 3 (tiga) jenis sanksi administrasi, yaitu; paksaaan pemerintahan (Pasal 25 ayat (1), ayat (2), ayat (3), dan ayat (4) UUPLH); uang paksa (Pasal 25 ayat (5) UUPLH); dan pencabutan izin usaha dan/atau kegiatan (Pasal 27 ayat (1) UUPLH).

Penjatuhan sanksi administratif dalam Pasal 25 disebutkan bahwa Gubernur berwenang melakukan paksaan pemerintahan (bertuursdwang) terhadap penanggung jawab usaha dan atau kegiatan untuk mencegah dan mengakhiri terjadinya pelanggaran, serta

${ }^{14}$ Mas Achmad Santoso dan Sulaiman N. Sembiring, Hak Gugat Organisasi Lingkungan (Environmental Legal Standing) (Jakarta: ICEL, 1997), hlm. 11 - 12.

${ }^{15} \mathrm{lbid}$, hlm. 12 - 14. 
menanggulangi akibat yang ditimbulkan oleh suatu pelanggaran, melakukan tindakan penyelamatan, penanggulangan, dan atau pemulihan atas beban biaya penanggung jawab usaha dan atau kegiatan. Sanksi administratif yang berupa paksaan pemerintahan itu dapat diganti dengan pembayaran sejumlah uang tertentu atau yang dikenal dengan istilah dwangsom. ${ }^{16}$ Penetapan besarnya dwangsom tersebut sudah barang tentu harus berdasarkan perhitungan ilmiah atas berapa besar biaya yang harus dikeluarkan untuk memulihkan lingkungan yang telah rusak dan atau tercemar itu.

Penjatuhan sanksi tersebut juga dapat dilakukan atas permohonan yang diajukan oleh pihak ketiga yang berkepentingan (para korban atau organisasi lingkungan/LSM lingkungan). Meskipun secara formal, mungkin para korban atau LSM lingkungan belum pernah mengajukan permohonan penjatuhan sanksi paksaan pemerintahan itu, namun hal itu sudah menjadi wewenang Gubernur. Karena, berdasarkan pasal tersebut, penjatuhan sanksi administratif yang berupa paksaan pemerintahan itu tidak harus melalui permohonan dari pihak ketiga yang berkepentingan.

Gubernur dapat melimpahkan wewenang itu (delegation) kepada Bupati/ Walikota dengan suatu Peraturan Daerah. Oleh karena itu, sepanjang belum ada pelimpahan wewenang itu, maka Bupati/ Walikota tidak memiliki wewenang untuk menjatuhkan sanksi administratif yang berupa paksaan pemerintah itu kepada pelaku perusakan atau pencemaran lingkungan, apalagi untuk menuntut ganti kerugian. Begitu juga DPRD, adalah sah-sah saja membentuk Tim untuk menghitung kerugian yang ditimbulkan oleh akibat perusakan atau pencemaran itu. Namun, harap diingat bahwa DPRD tidak memiliki kewenangan untuk memaksakan pencemar untuk membayar ganti kerugiannya. Hak untuk menuntut besamya ganti kerugian tetap ada pada pihak korban. Hasil penelitian yang dilakukan oleh Tim yang dibentuk oleh DPRD tersebut hanyalah berfungsi sebagai masukan bagi pihak korban untuk. menentukan besarnya ganti kerugian atau bagi Gubernur untuk menentukan besarnya biaya pemulihan lingkungan sebagai bagian dari penerapan sanksi administratif.

Di samping itụ, perlu juga diketahui bahwa meskipun nantinya sudah ada kesepakatan antara para korban dan pelaku perusakan atau pencemaran lingkungan untuk menyelesaikan kasus ini melalui di luar pengadilan, hal itu tidak menutup mata hati dan langkah Gubernur (Walikota/Bupati apabila mendapatkan pelimpahan wewenang) untuk menjatuhkan sanksi administratif yang berupa paksaan pemerintahan atau dwangsom, serta Polisi atau PPNS untuk memeriksa adanya tindak pidana di bidang lingkungan hidup untuk kasus tersebut.

Jenis sanksi administratif lainnya yang dikenal dalam UUPLH adalah pencabutan izin usaha/kegiàtan sebagaimana yang disebutkan dalam Pasal 27 ayat (1) UUPLH. Pejabat yang berwenang untuk mencabut izin

${ }^{16}$ Philipus M. Hadjon, "UU Nomor 23 Tahun 1997 dan Penegakan Hukumnya Ditinjau dari Aspek Hukum Administrasi," Makalah Disampaikan pada Seminar Nasional yang diselenggarakan oleh Fakultas Hukum Universitas Dipanegoro, Semarang, 21 Februari 1998, hlm. 10. 
usaha/kegiatan yang telah melakukan perusakan atau pencemaran lingkungan itu adalah pejabat yang mengeluarkan atau menerbitkan izin usaha/kegiatan itu. Hal ini sejalan dengan asas contrarius actus yang mengatakan bahwa pejabat yang memiliki wewenang untuk mencabut izin adalah pejabat yang mengeluarkan izin itu sendiri. Namun; dalam Pasal 27 ayat (2) UUPLH disebutkan bahwa apabila yang mengeluarkan atau menerbitkan izin tersebut bukan Kepala Daerah, maka Kepala Daerah tersebut dapat mengusulkan kepada pejabat yang berwenang yang mencabut izin dari perusahaan yang telah melakukan perusakan atau pencemaran lingkungan di daerahnya.

Sementara itu sanksi tindakan tata tertib sebagaimana yang disebutkan dalam Pasal 47 UUPLH yang berupa:

a. perampasan keuntungan yang diperoleh dari tindak pidana; dan atau

- b. penutupan seluruhnya atau sebagian përüsanaan; dan atàu

c. perbaikan akibat tindak pidana; dan atau

d. mewajibkan mengerjakan apa yang dilalaikan tanpa hak; dan atau

e. meniadakan apa yang dilalaikan tanpa hak; dan atau

f. menempatkan perusahaan di bawah - pengampuan paling lama 3 tahun, ditempatkan sebagai bagian dari sanksi pidana, sehingga menjadi wewenang jaksa untuk melakukan penuntutannya. Dengan demikian, penjatuhan jenis-jenis sanksi tersebut harus terlebih dahulu melalui putusan pengadilan yang telah memiliki kekuatan hukum yang mengikat.

Apabila dilihat dari jenis-jenis sanksi yang disebutkan dalam Pasal 47 UUPLH tersebut, maka sebenarnya lebih bersifat administratif.
Oleh karena itu, penerapan ketentuan Pasal 47 UUPLH tersebut sudah semestinya memperhatikan penerapan Pasal 25 dan Pasal 27 UUPLH agar tidak menimbulkan kerancuan dan tumpang tindih dalam penjatuhan sanksi.

\section{Penjatuhan Sanksi Pidana Lingkungan}

Setiap terjadi kasus perusakan atau pencemaran lingkungan, maka Polisi atau PPNS yang lingkup tugas dan tanggung jawabnya di bidang lingkungan memiliki wewenang untuk memeriksa, meminta keterangan, bahan bukti, dan sebagainya terhadap orang atau badan hukum yang diduga melakukan tindak pidana di bidang lingkungan hidup (Pasal 40 UUPLH). Namun, sampai sejauh ini, Polisi atau PPNS yang dimaksud belum secara otomatis dengan cepat melakukan tugas dan tanggung jawabnya itu. Polisi atau PPNS yang dimaksud di samping terkesan agak lamban dalam melaksanakan tugas tersebut juga masih ada yang berpendapat bahwa pidana lingkungan merupakan delik aduan. Padahal jelas sekali berdasarkan pasal-pasal yang dikemukakan di atas bahwa pidana lingkungan menurut UUPLH bukan merupakan delik aduan.

Berdasarkan ketentuan Pasal 41, 42, 43, 44, 45, 46, dan Pasal 47 UUPLH dapat diketahui bahwa jenis-jenis sanksi pidana yang dapat diancamkan kepada pelaku perusakan atau pencemaran lingkungan adalah pidana penjara, denda, dan atau tindakan tata tertib. Jenis sanksi pidana yang berupa pidana penjara dan denda bersifat komulatif.Sedangkan jenis sanksi pidana yang berupa tindakan tata tertib lebih bersifat diskresi, sehingga sepenuhnya diserahkan 
kepada kebijaksanaan dari penuntut umum (jaksa). Pasal 41, 42, 43, dan Pasal 44 UUPLH berkaitan dengan sanksi pidana yang dapat diancamkan kepada pelaku perusakan atau pencemaran lingkungan yang dilakukan oleh individu. Pasal 45 dan Pasal 46 UUPLH adalah sanksi pidana yang dapat diancamkan kepada pelaku perusakan atau pencemaran lingkungan yang dilakukan oleh korporasi. Sedangkan ketentuan Pasal 47 adalah sanksi pidana yang dapat diancamkan kepada pelaku perusakan atau pencemaran lingkungan yang dilakukan baik oleh individu maupun korporasi. Untuk lebih jelasnya dapat digambarkan sebagai berikut:

\begin{tabular}{|c|c|c|c|}
\hline Pasal & Pelaku & Perbuatan yg dilarang & Saksi \\
\hline $\begin{array}{l}\text {-Pasal } 42 \\
\text { ayat (1). } \\
\text {-Pasal } 42 \\
\text { ayat (2). }\end{array}$ & -individu & 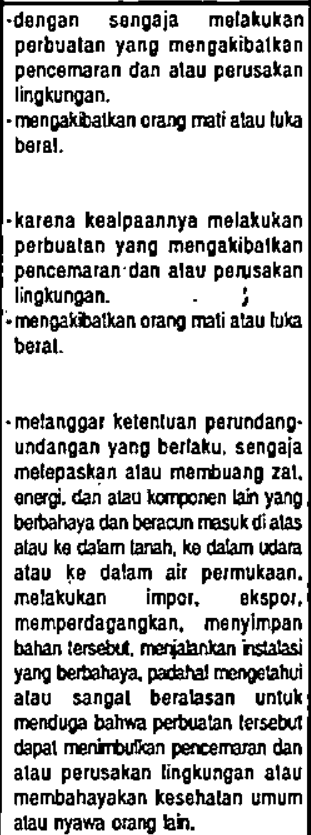 & $\begin{array}{l}\text { - penjara max } \\
\text { io it dan } \\
\text { denda max } \\
\text { Ap } 500 \text { jula. } \\
\text { - penjara max } \\
\text { is th dan } \\
\text { denda max } \\
\text { Pp } 750 \text { jula. } \\
\text { - penjara max } \\
3 \text { it dan } \\
\text { denda max } \\
\text { Rp ion juta. } \\
\text { - perjara max } \\
\text { th dan denda } \\
\text { max Ap } 150 \\
\text { jula. } \\
\text { - penjara max } 6 \\
\text { th dan denda } \\
\text { max. Pp } 300 \\
\text { juta. }\end{array}$ \\
\hline
\end{tabular}

\begin{tabular}{|c|c|c|c|}
\hline Pasal & Pelaku & Perbuatan yg dilarang & Saksi \\
\hline $\begin{array}{c}\text {-Pasal 44 } \\
\text { ayat (1) } \\
\text {-Pasal 44 } \\
\text { ayat (2) }\end{array}$ & $\begin{array}{c}\text {-individu } \\
\text {-individu } \\
\text { - korporas }\end{array}$ & 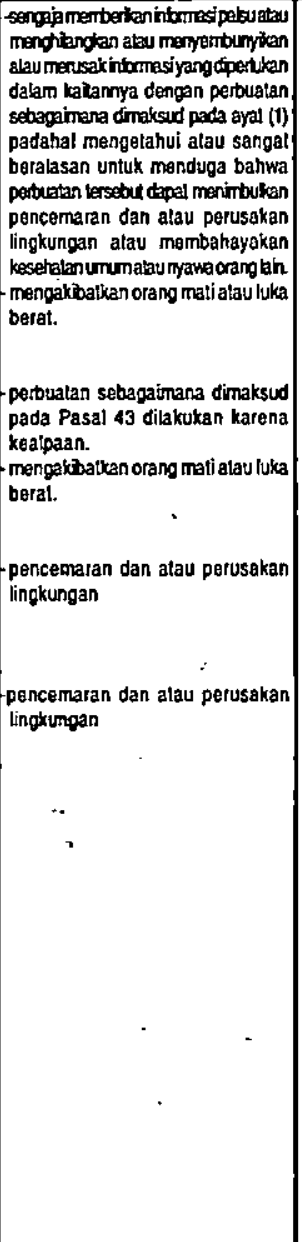 & 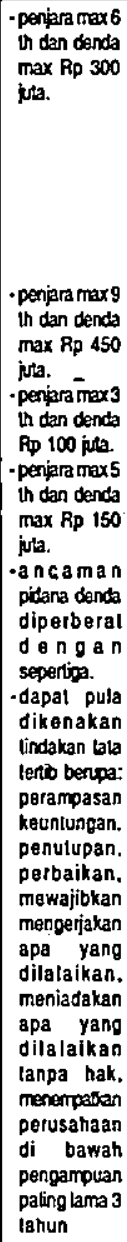 \\
\hline
\end{tabular}

Dari rumusan Pasal 41, Pasal 42, dan Pasal 43 UUPLH dapat diketahui bahwa pasalpasal tersebut merupakan delik materiil ${ }^{17}$ yang membawa konsekuensi pembuktian adanya hubungan kausalitas antara perbuatan perusakan dan. atau pencemaran lingkungan dan akibat yang ditimbulkan, yaitu rusaknya dan atau tercemarnya lingkungan hidup yang

${ }^{17}$ Muladi, op.cit, hlm. 23. 
dimaksud. Berbeda halnya dengan Pasal 44 UUPLH lebih merupakan delik formil ${ }^{18}$ yang membawa konsekuensi bahwa yang penting dapat membuktikan perbuatan melanggar hukumnya. Sedangkan apakah perbuatan tersebut telah mengakibatkan terjadinya perusakan dan atau pencemaran lingkungan adalah tidakiah penting.

Sementara itu, berdasarkan rumusan Pasal 45 dan Pasal 46 UUPLH yang mengatur tentang-tindak pidana lingkungan yang dilakukan oleh korporasi tidak memiliki kejelasan tentang apakah pemimpin korporasi dan atau mereka yang memberi perintah dapat diancam dengan sanksi pidana yang berupa pidana penjara. Memang, dalam Pasal 46 UUPLH disebutkan kemungkinan pemimpin korporasi dan atau mereka yang memberi perintah dijatuhi sanksi pidana baik berupa pidana penjara dan denda (sebagaimana sanksi pidana yang terdapat dalam Pasal 41 Pasal 44 UUPLH) dan atau tindakan taat tertib (sebagaimana yang terdapat dalam Pasal 47 UUPLH). Namun, hal itu menjadi rancu dengan ketentuan pasal 45 UUPLH yang menyebutkan bahwa jika perbuatan-itu dilakukan oleh korporasi ancaman pidana dendanya diperberat dengan sepertiga. Kerancuan itu dapat dijelaskan bahwa ancaman sanksi yang terdapat dalam Pasal 41 - 44 UUPLH bersifat komulatif, sementara apabila mengacu kepada Pasal 45 dan 46 UUPLH terjadi pemisahan antara ancaman pidana penjara yang ditujukan kepada pemimpin korporasi dan atau kepada mereka yang memberi perintah, sedangkan ancaman dendanya ditujukan kepada korporasinya. Atas dasar itu, maka sanksi pidana yang sudah jelas dapat diancamkan hanya terhadap korporasi, yaitu berupa pidana denda yang diperberat dengan sepertiga, sedangkan terhadap pemimpin korporasi dan atau mereka yang memberi perintah tidak jelas apakah hanya dapat dikenakan dapat pidana penjara saja, atau pidana penjara dan denda, atau pidana penjara, denda, dan tindakan tata tertib. Jika hanyadikenakan kemungkinan yang pertama, maka hal itu tidak sejalan dengan ketentuan pasal 41 - 44 UUPLH yang menganut sifat komulatif. Sementara, apabila dikenakan kemungkinan kedua, berarti terjadi penggandaan, penjatuhan sanksi pidana yang berupa denda, yakni; denda yang dijatuhkan kepada korporasi dan kepada pemimpin korporasi dan atau mereka yang memberi perintah. Begitu juga, apabila dikenakan kemungkinan yang ketiga, mejadi tidak rasional, karena pemimpin korporasi dan atau mereka yang memberi perintah tidak mungkin dapat dikenakan sanksi pidana yang berupa tindakan tata tertib.

Di samping itu, korporasi juga dapat dikenakan sanksi yang berupa tindakan tata tertib sebagai mana yang disebutkan dalam Pasal 47 UUPLH. Untuk jenis sanksi pidana yang terakhir tersebut relatif sifatnya. Dengan kata lain, tidak setiap kasus pidana lingkungan otomatis dikenakan sanksi pidana nyang berupa tindakan tata tertib tersebut.

Berangkat dari rumusan Pasal 45 dan Pasal 46 UUPLH di satu pihak dan rumusan Pasal 41, Pasal 42, Pasal 43, dan Pasal 44 UUPLH di pihak lain, maka jelas sekali bahwa perusakan dan atau pencemaran lingkungan yang dilakukan oleh individu.

Berangkat dari rumusan Pasal 45 dan

${ }^{18} \mathrm{lbid}$. 
Pasal 46 UUPLH di satu pihak dan rumusan Pasal 41, Pasal 42, Pasal 43, dan Pasal 44 UUPLH di pihak lain, maka jelas sekali bahwa perusakan dan atau pencemaran lingkungan yang dilakukan oleh individu ancaman hukumannya menjadi lebih berat daripada yang dilakukan oleh korporasi. Ancaman hukuman yang dapat dikenakan kepada individu yang melakukan perusakan dan atau pencemaran lingkungan terdiri atas pidana penjara dan denda, dan atau tindakan tata tertib. Tidak jelas, apa yang menjadi latar belakang dari para pembuat UUPLH, sehingga ancaman hukuman terhadap perusakan dan atau pencemaran lingkungan yang dilakukan oleh individu lebih lengkap dan lebih jelas (pidana penjara dan denda, dan atau tindakan tata tertib) daripada apabila pelakunya adalah korporasi.

\section{Simpulan}

Penegakan hukum lingkungan menurut UUPLH dapat dilakukan secara preventif dan secara represif. Penegakan hukum lingkungan secara preventif ditujukan langsung untuk mencegah terjadinya perusakan dan atau pencemaran lingkungan. Instrumen hukum yang dapat digunakan adalah instrumen hukum administrasi yang berupa kewajiban yang diletakkan bagi setiap orang yang akan menjalankan suatu usaha atau kegiatan (pemrakarsa) untuk terlebih dahulu memiliki dokumen AMDAL dan atau izin.

Penegakan hukum lingkungan secara represif ditujukan langsung untuk menanggulangi perusakan dan atau pencemaran lingkungan. Instrumen hukum yang dapat digunakan adalah instrumen hukum administrasi, hukum perdata, dan hukum pidana. Penegakan hukum administrasi terhadap perusak dan, atau pencemar lingkungan dapat dilakukan dengan menjatuhkan sanksi administrasi yang berupa paksaan pemerintahan atau uang paksa, dan selanjutnya sampai kepada pencabutan izin oleh pejabat yang berwenang tanpa melalui putusan pengadilan.

Penegakan hukum perdata dapat dilakukan dengan para korban atau LSM mengajukan ke pengadilan. Sedangkan penegakan hukum pidana dapat dilakukan dengan menyeret pelaku perusakan dan atau pencemaran lingkungan (individu atau korporasi) ke pengadilan. Penjatuhan sanksi administrasi, gugatan ganti kerugian dan pemulihan lingkungan, serta tuntutan pidana yang dilakukan terhadap pelaku perusakan dan atau pencemarn lingkungan dalam kasus yang sama bukan merupakan, ne bis in idem.

\section{Daftar Pustaka}

Arief, Barda Nawawi, Masalah Penegakan Hukum dan Kebijakan Penanggulangan Kejahatan, Bandung: Penerbit PT. Citra Aditya Bakti, 2001,

B, Bruce Mitchell, Setiawan, dan Dwita Hadi Rahmi, Pengelolaan Sumberdaya dan Lingkungan, Yogyakarta: Gadjah Mada University Press, 2000.

Emirzon, Joni, Alternatif Penyelesaian Sengketa di Luar Pengadilan (Negosiasi, Mediasi, Konsiliasi \& Arbitrase), Jakarta: PT Gramedia Pustaka Utama, 2000.

Hadjon, Philipus $M$, "UU Nomor 23 Tahun 1997 dan Penegakan Hukumnya Ditinjau dari Aspek Hukum 
Administrasi," Makalah Disampaikan pada Seminar Nasional yang diselenggarakan oleh Fakultas Hukum Universitas Dipanegoro.

Hadjon, Philipus M, Penegakan Hukum Administrasi dalam Pengelolaan Lingkungan Hidup, dalam B. Arief Sidharta, dkk (Editor), Butir-butir Gagasan tentang Penyelenggaraan Hukum dan Pemerintahan yang Layak, Bandung: Penerbit PT. Citra Aditya Bakti,.1996.

Lotulung, Paulus Effendie, "Penegakan Hukum Lingkungan dalam UU 23 Tahun 1997 Ditinjau dari Aspek Hukum Perdata," Makalah Disampaikan pada Seminar:- Nasional yang diselenggarakan oleh Fakultas Hukum Universitas Dipanegoro, Semarang.

Muladi, "Prinsip-prinsip Dasar Hukum Pidana Lingkungan dalam Kaitannya dengan UU Nomor 23 Tahun 1997," Makalah Disampaikan pada Seminar Nasional yang Diselenggrakan oleh Fakultas Hukum Universitas Dipanegoro, Semarang, 21 Februari 1998.

Pinakunary, Fredrik J, Penerapan Tanggung Jawab Pidana Mutlak Pada Perkara Pencemaran Lingkungan, http://www. hukumomline. $\mathrm{com} /$ detail.asp?id=10837\& cl=Kolom, diakses tanggal 26 November 2004, jam 13.20 WIB.

Rangkuti, Siti Sundari, Hukum Lingkungan dan Kebijaksanaan Lingkungan Nasional, Edisi Kedua, Surabaya: Airlangga University Press, 2000.

Santosa, Mas Achmad, dkk, Gugatan Claas Action, Jakarta: ICEL, 1999.

Santoso, Mas Achmad dan Sulaiman N. Sembiring, Hak Gugat Organisasi Lingkungan (Environmental Legal Standing), Jakarta: ICEL, 1997.

Soemarwoto, Otto, Ekologi, Lingkungan Hidup dan Pembangunan, Cetakan Keenam, Jakarta: Penerbit Djambatan, 1994.

Susanti Adi Nugroho, Praktek Gugatan Perwakilan Kelompok (Class Action) di Indonesia, Jakarta:. Mahkamah Agung $\mathrm{RI}, 2002$.

West, Bernadette, Peter M. Sandman, dan Michael R. Greenberg, Panduan Pemberitaan Lingkungan Hidup, Jakarta: Yayasan Obor Indonesia,.1998.

Widiati, Sri (Penterjemah), Planet Kita Kesehatan Kita: Laporan Komisi WHO Mengenai Kesehatan dan Lingkungan, Yogyakarta, Gadjah Mada University Press, 2001.

Widjaja, Gunawan, Alternatif Penyelesaian Sengketa, Jakarta: Rajawali Pers, 2001. 